\title{
Lightening up on the Ad Hominem ${ }^{1}$
}

\author{
JoHn WoOdS
}

\author{
University of British Columbia \\ King's College, London
}

\begin{abstract}
In all three of its manifestations, -abusive, circumstantial and tu quoquethe role of the ad hominem is to raise a doubt about the opposite party's casemaking bona-fides.Provided that it is both presumptive and provisional, drawing such a conclusion is not a logical mistake, hence not a fallacy on the traditional conception of it. More remarkable is the role of the ad hominem retort in seeking the reassurance of one's opponent when, on the face of it, reassurance is precisely what he would seem to be ill-placed to give. Brief concluding remarks are given over to an examination of rival approaches to the ad hominem, especially those in which it is conceived of as a dialectical error.
\end{abstract}

Résumé: Le rôle du sophisme ad hominem dans toutes ses manifestations - abusives, circonstancielles, et $t u$ quoque-est de soulever le doute d'un adversaire. Pourvu que ce doute soit une présomption provisoire, il n'y a pas d'erreur logique, et donc il n'y a pas de sophisme au sens traditionnelle de ce mot. Ce qui est plus remarquable est le rôle de la riposte $a d$ hominem qui recherche l'assurance d'un adversaire lorsque celui-ci est mal placé pour la donner. Je termine avec quelques brèves remarques sur l'examen d'approches rivales sur l'ad hominem, en particulier celle qui le conçoit comme une erreur dialectique.

Keywords: ad hominem, Aristotle, DeMorgan, dialectic, fallacy, Locke, logic, informant, normativity, plausibility, pragma-dialectics, reassurance, refutation, rhetoric, slanging, Walton

\section{Four preliminaries}

It is advisable to get some things clear at the outset, beginning with slanging. There are two impulses for the ad hominem. One is rhetorical. The other is logical. Ad hominem remarks are the heart and soul of slanging. Slanging is a rhetorical device, as old as the hills. Its objective is to expose, embarrass, ridicule, mock, calumniate or humiliate one's opponent, typically with the intent of rattling him dialectically. One of the heavyweight slangers of the western intellectual tradition was Rabelais. Reflecting on how his ideal Academy should be constituted, Rabelais indulged in some rather aggressive exclusions. He was especially hard on lawyers and, as we now call them, professors of management. 
Enter not base pinching Usurers,

Pelf-lickers, everlasting gatherers.

Gold-graspers, coin-grippers, gulpers of mists:

Niggish deformed sots, who, though your chests

Vast summes of money should to you afford,

Would ne'ertheless adde more unto that horde,

And yet not be content, your clenchfist dastards,

Insatiable fiends, Plutoes bastards,

Greedie devourers, chichi sneakbill rogues,

Hell-mastiffs gnaw your bones, you rav'nous dogs. ${ }^{2}$

Getting right the rhetorical textures of verbal abuse is a trickier task than might be supposed, but one thing can be said without much ado. It is that there is no intrinsic tie between slanging and the negative assessment of an opponent's case. Slanging isn't argument-assessment. Since, in the logical tradition, this latter is precisely what the ad hominem purports to be, the logical tradition has no interest, as such, in slanging. What logicians want to know is whether the ad hominem is ever a legitimate part of argument-assessment. In particular, they want to know whether it is a fallacy.

A second issue is how the idea of fallacy is standardly conceived. On the traditional conception of it, a fallacy is an error that is attractive, universal and incorrigible. This gives us the acronym, EAUI, which has the attraction of being pronounceable as "Yowee" (Woods 2004, chapter 1). ${ }^{3}$ Its universality is not of the literal kind. It encompasses two factors that render it more a generic property than a strictly invariable one. One is that it is an error committed with a notable frequency. The other is that it is an error that doesn't respect divisions of culture, race, sex and so on. Its incorrigibility encompasses generally high levels of post-diagnostic recidivism. Its attractiveness is a composition of the prior three-it is a mistake widely committed and hard to avoid and to correct.

A third preliminary takes the form of a confession. I have of late given up on the Gang of Eighteen, and have found myself drawn to the following two theses. ${ }^{4}$

The negative thesis. The members of the Gang of Eighteen are either not errors or, when they are, are not typically committed by beings like us, hence are not fallacies either way.

The positive thesis. For the most part, the Eighteen are benign strategies designed to adjust the individual reasoner to his comparatively scant cognitive resources.

It is not my intention to expatiate on these claims here, beyond saying that if the negative thesis is true, then it is trivial that the ad hominem is not a fallacy and is, therefore, a manoeuvre that should be lightened up on. What I shall do instead is 
baldly outline the case for the negative thesis, and then move on to try to liberate the ad hominem in ways that are independent of it.

The negative thesis depends on the EAUI-notion of fallacy. It makes no inroads against, say, the pragma-dialectical conception. But the EAUI-conception matters. It is the traditional idea. The case for the negative thesis proceeds as follows.

1. Something is an error of reasoning only in relation to the agent's cognitive target and the attainment-standard it embeds.

2. Logicians to date have concentrated their attention on the targets of truth-preservation and experimental confirmation, and the embedded attainment-standards of validity and inductive strength.

3. If the empirical record in anything to go on, in most situations in which an individual reasons his target is neither truth-preservation nor experimental confirmation. Nearly always these are inappropriate to his situation or beyond his reach, or both.

4. Accordingly, one finds that in his actual reasoning, an individual rarely meets or has need of meeting the standards of validity or inductive strength.

5. Most good reasoning by individual reasoners satisfies conditions (3) and (4).

6. In their appraisal of the Eighteen, the charge that logicians standardly bring is that they are reasonings that are invalid or inductively weak.

7. This is true, but given the above, they are hardly ever errors.

8. So, when committed by beings like us, they are not fallacies.

The fuller case I am in process of working out in work underway. For the present, I simply want to come clean about it and register its gist. The business of the present paper is to free the ad hominem from the charge of fallacy without having to invoke the negative thesis.

Now for our last preliminary remark. In a good many treatments of it, an ad hominem remark is addressed to one's interlocutor, and in a good many of these situations the interlocutor is expected to provide some kind of answer. In actual practice, of course, and ad hominem is often addressed to a third party, and in lots of cases it is left to the third party to take the measure of the retort and to furnish whatever answer may be possible for it. In still further cases, as in a scientific or scholarly article or op-ed piece for the Times, the subject of a remark ad hominem might be Harry, but its addressees are the piece's readers, what Trudy Govier calls the "non-interactive audience". While some responses are possible by way of the Replies section of the academic journal or a letter to the editor, it is not typical of this situation that ad hominem challenges are responded to. In what follows, I confine my remark to cases in which the subject and addressee of an ad hominem 
retort are one and the same person. However since most of what is said here about these cases generalizes in a quite natural way to the others, nothing essential is lost by imposing this restriction. For an exception, see the section to follow.

\section{Damaging information}

David Hitchcock has recently done us the service of demonstrating that the ad hominem has been a fallacy only since the mid-nineteenth century. ${ }^{5}$ De Morgan appears to have been the first to propose that it involves a logical error-indeed, as De Morgan sees it, it commits the fallacy of ignoratio elenchi (1847, 308-309), which he characterizes "as answering to the wrong point" (Hitchcock 2006, 1). Argumenta ad hominem were discussed by Aristotle in book Gamma of the Metaphysics. They also captured the attention of mediaeval thinkers and were part of the standard fare of post-Renaissance logic until the 1800s. In all that time, they were interesting to logicians, but not because they were fallacies. ${ }^{6}$ Hitchcock's view is that the by now received understanding of these arguments as fallacies is in fact a common misconception, hence a fallacy in its own right. ${ }^{7}$ I think that Hitchcock is right about this.

I have a particular and twofold purpose in this paper. Echoing the two theses that we have just met with, I want to produce reasons in addition to those put forward by Hitchcock for the negative thesis that ad hominem arguments are not fallacies. I want also to suggest a positive thesis, according to which ad hominem remarks play a natural and dialectically benign role in the give-and-take of real-life argumentation.

Before turning to these two matters, a brief taxonomic interlude would be in order. Modern writers commonly divide the ad hominem into three distinct typesabusive, circumstantial and tu quoque. The abusive variety involves the attribution to a party to an argument of a fact that reflects badly on his character. Circumstantial ad hominems attribute to a party a feature that reflects badly on his bona fides as a case-maker. Pointing out that one's opponent is a liar is thought to fit the abusive category, whereas claiming that one's opponent is afflicted with a serious bias for or against the issue presently in contention is usually thought to fit into the circumstantial category. As far as I can see, lying fits into both, and, if it didn't fit into the second, it would be difficult to fathom the rationale for of its membership in the first. More generally, I find these contrasts to be insufficiently marked to warrant taxonomic specification. But this is not a matter that I'll be pursuing here.

Ad hominems of the tu quoque variety are usually identified as remarks against an adversary which impute to him a pragmatic inconsistency between the position he holds and his own behaviour in regard to it. One would make a tu quoque move against an anti-smoking advocate by pointing out that, after all, he himself is a smoker. I also have reservations about the contrastive utility of this classification. What would be the relevance of a smoking anti-smoker if pointing this out didn't 
also fall into the "circumstantial" slot? But here, too, in the interests of space I'll not press the point.

It is instructive to begin our enquiry with Aristotle. Remarks in the Metaphysics $\left(\mathrm{XI5}, 1062^{\mathrm{a}} 2-3\right)$ make it plain that the arguments which Aristotle describes in $\mathrm{On}$ Sophistical Refutations as refutations are arguments ad hominem. ${ }^{8}$ Unlike Locke, Aristotle does not make this attribution expressly, but there is no doubt that his refutations are a species of Locke's ad hominem, according to which one party presses another "with consequences drawn from his own principles or concessions" (Locke 1690/1975, 686). In Aristotle's case, one party refutes the thesis of another party by constructing a syllogism that meets the following three conditions.

1) The conclusion of the syllogism is the contradictory of the opponent's thesis.

2) The premisses of the syllogism without exception are propositions either expressly conceded by the opponent or to which he is obviously committed by virtue of such concessions.

3) The premisses of the syllogism without exception arise as answers to Yes-No questions put by the would-be refuter.

When a refutation succeeds, its addressee convicts himself out of his own mouth of logical inconsistency. ${ }^{9}$ How, one wonders, could this be a fallacy?

One of the virtues of Aristotle's approach is that disputes that honour conditions (1) to (3) are hermetically sealed against begging the question. When a refutation succeeds, the refuted party has only himself to blame. While the avoidance of question-begging is clearly a benefit, it also carries a cost. The cost is that Aristotelian refutation-arguments are unnatural to work with and subject to significant inefficiencies.

In contrast, in the real-life adjudication of contested issues, parties routinely supply their own premisses. Such premisses typically arise in one or other of two common situations. In one, the premiss is a proposition in the common knowledge of the parties, hence is one that doesn't need to be "asked for". In the other, the premiss furnishes the reply to a question which, had it been put to him, the party under attack would not be able to answer. Here the antagonist (or the critic) plays the role of informant. It is precisely at this point that Aristotle's rules dig in deeply. Aristotle requires that the refuting party never play the role of informant, and that when his interlocutor is unable to answer, his ignorance must be removed by supplementary questioning. The classical paradigm of the dialectical removal of ignorance is the Slave-Boy argument of Plato's Meno (1980, 353-354). Everyone familiar with this celebrated text will be aware that Socrates' interrogation is both argumentatively artificial and rather lengthy. 
Ad hominem remarks are a way of alerting us to the danger of relying on one's interlocutor for information intended to be used to one's disadvantage. Suppose that Harry and Sarah initially disagree as to whether Lou was at dinner with another woman last night, Sarah's case might have constructed along the following lines. "I know Lou. He wouldn't do that. Besides he had an 8:00 appointment in Cambridge yesterday evening. On top of that, I happen to know that he dislikes that woman". Still, Harry's "Well, I saw him with her" is decisive against Sarah if she accepts the information that his utterance encodes. Certainly she would have no good reason to accept this claim if she thought that Harry was outright lying or that in the heat of the moment he was being economical with the truth by misrepresentation or omission or confusion. But if she trusts Harry, this would be reason to accept what he says and, with it, the defeat of her original claim. There is an edgy tension here- or at least the prospect of it. In informing Sarah, Harry's intention is not, as such, to do Sarah the favour of passing on a scandalous tidbit about some matter of interest to her. His more fundamental purpose is to defeat her contrary case with it. Each party has an interest. Harry's interest lies in getting Sarah to accept information that damages her position, and Sarah's interest lies in resisting information that damages her position. We may say that Sarah has a stake in playing by something like Aristotle's rigid rules. The trouble is that in real-life situations Sarah's defensiveness would be seen as unrealistic and pig-headed.

Any form of argument that permits an aggressor to introduce damaging information on his own sayso is at risk for the contaminations of misrepresentation, omission and outright falsehood. When an argument is a serious one about a matter that touches the vital interests of the parties (e.g., whether the Netherlands' policy on assisted suicide is morally defensible), it matters considerably that the parties correctly assess the informational bona fides of their interlocutors. If I, as a foreigner, fall into a dispute with Gerda about this issue, it is likely that Gerda's case will rest on a good deal of factual information which, but for her advancement of it to me, I would not have in my possession and whose relevance I could not assess. But if she is the source of it, it matters whether she is a reliable informant.

On the face of it, the safer tactic is to refuse the sayso of an antagonist whenever the proferred information is damaging to the defendant's position on a matter that is vital to her. More particularly when Sarah has reason to think that Harry is a liar, she has reason to refuse anything he tells her if it proves damaging to the position she is defending. ${ }^{10}$ In fact, however this is often what does not happen. Ad hominems don't typically reject the proferred information. What is more, they often seek the informant's testamentary re-assurance.

Bearing on this is the quite general fact of our dependency on the sayso of others for most of what we know and for the bases on which most of our decisions to act are taken. So entrenched is the disposition to trust informants that it is comparatively difficult to refuse the information that others direct our way. A measure of this entrenchment is the frequency of our mollification by liars. This creates a default. Unless otherwise indicated, it is better to accept rather than 
reject the sayso of others. ${ }^{11}$ It is rather striking, then, that information preferred on the sayso of an opponent that damages one's own position does not, just so, override that default.

If the empirical record is anything to go on, the burden of proof falls on Sarah to show cause for not accepting Harry's damaging information. This burden is not discharged by pointing out that Harry's proffered information has a destructive motivation. If this is right, then remarks ad hominem are often the addressee's sole means of meeting this burden. If Sarah knows, or has reason to believe, that Harry is a liar, may she not properly resist his information on that basis, and may she not tell him so? If, contrary to what I have just suggested, she did reject his information on that basis, this would be an "abusive" ad hominem in the old taxonomy. It would not be a mistake unless she concluded in some quite strict way from the fact that Harry is a liar that Harry's claim must be false. Either way, no fallacy is committed. In the first instance this is because no error is committed. In the second instance, this is because the error is so egregious that hardly anyone would ever be drawn to it. It is an error that lacks the frequency of committal required to make it a fallacy.

Similarly, if Sarah's ad hominem retort were that Harry carries a bias against her position, this would be "circumstantial" ad hominem in the old classification. Unlike the previous case, in which Sarah expresses doubt as to whether she can trust Harry, in the present kind of case Sarah's worry is often also about whether Harry can trust himself. For, in one of its common manifestations, bias "closes minds." ${ }^{12}$ Someone caught in the grip of a bias can be adversely affected in two main ways. He can assign an undue weight to the evidence for his own position and less than due weight to counterevidence. The other is that he may fail to take proper note of the opponent's case. In the first instance, in effect he tampers with the evidence. In the second he omits to hear it. Of course, in each case, this often happens unawares.

Here too it would be a blatant mistake if Sarah were to conclude from the fact of his bias that Harry's position on doctor-assisted suicide must be false. But this still gives her lots of room for manoeuvre. In particular, she has reason to suspect that Harry's case against it is defective, and is made so by the distortions occasioned by bias. At the heart of this sort of worry is the foundational fact that real-life arguments nearly always constitute themselves in non-monotonic contexts. Accordingly, a case for $\alpha$ is well-made to the extent to which there are sound reasons for $\alpha$ and the reasons for $\alpha$ trump the reasons against it. A case for a claim that does not include some consideration of the case against it lies exposed to the risk that the unconsidered evidence will trump the considered evidence. Someone who is hostage to bias may, then, be excessively preoccupied with favourable evidence and not sufficiently alert to the possibility — and the strength of counterevidence. When Sarah voices her concern about Harry's bias, she enters what in (Johnson 2000) is called the "dialectical tier". Sarah may have it in mind 
that Harry's is offering an over-narrow case for his position. If Sarah is disposed to accept an opponent's sayso when it comes to information that damages her position, she is surely entitled to expect her opponent also to acknowledge information that might support it. ${ }^{13}$

A further instance of the so-called circumstantial ad hominem is one in which an interlocutor's pre-commitment is challenged. If Sarah knows that Harry is a devout Catholic, she may be troubled by the fact that Harry's opposition to doctorassisted suicide is an obligation of his faith, hence not free in Mill's sense. If, thus positioned, Harry is parti pris, how likely is it that he will be open to Sarah's defence? Equally, if Lou is communications director for the Liberal party, the same difficulties are also present. In each case, the views presented by someone who is parti pris are views to which he may be pledged irrespective of the merits of the case. This, too, constitutes a condition of bias, and places in some doubt the party's sincerity (thus, we may note in passing, blurring the distinction between circumstantial and abusive variants).

Suppose now that Harry is pressing the anti-smoking position on Sarah, and that Sarah's complaint is that Harry himself smokes, a kind of pragmatic inconsistency. ${ }^{14}$ In the old classification, this would be a "tu quoque" variety of the ad hominem. Sarah is accusing Harry of a kind of incontinence. In voicing to her doubts, a number of different motivations may be present, of which three are of particular importance. One is that in pointing out Harry's behavioural defection from his own policy, Sarah might be expressing a doubt as to whether Harry's actual position is the same as the position he has given voice to. Although Harry has said, "No one should smoke", perhaps what he really means is that no one should smoke to excess, or that young people shouldn't smoke. ${ }^{15}$ Another possibility is that Sarah is questioning an unspoken presupposition of Harry's position, namely, that the case he advances against smoking is sufficient to motivate a reasonable person to adjust his behaviour to it. If Harry himself fails to comport with his own policy, then Harry himself is either signalling the motivational inadequacy of his argument or disclosing his own unreasonableness. But if Harry is unreasonable in the way he handles the smoking issue, why should one suppose that the case he has assembled against it is sufficient to compel compliance? If Harry will not act reasonably about smoking, why should we think that he is reasoning reasonably about it? A third possibility is that Harry's defection signals a kind of insincerity. This would matter in those cases in which the dispute is aimed at getting to the truth of the matter about smoking, rather than a contest in which the parties merely "score off" against one another. If there is reason to think that Harry doesn't believe his own propaganda, why should Sarah accept his assurances? In (1992), Douglas Walton acknowledges that it sometimes is the intent of ad hominem remarks to raise questions about an informant's reliability. They may be used to raise six critical questions about what he calls "source-based evidence". The questions concern the consistency, honesty, sincerity, reliability, moral character and judgement of the source. (Walton 1992, 197-198). A difference between their 
account and my own is that Walton envisages the interlocutor and the subject of the ad hominem to be different persons. In the cases I consider, they are one and the same. This is one of the few respects in which the generalization from such cases to two-person cases is not entirely straightforward.

\section{Reassurance and dialectical persistence}

In the cases we have examined so far, it might again be insisted that the difficulties that trigger Sarah's ad hominem remarks constitute a sufficient ground to quit the argument at hand. If Sarah has reason to think that Harry is dishonest, biased, unreasonable or insincere, who would fault her for breaking off and searching out some more reliable interlocutor? Yet it bears repeating that perhaps the most remarkable feature of ad hominem retorts is that they mark not the complainant's decision to withdraw but rather her readiness to continue (at least for awhile). Unless I am mistaken, this is far and away the most important feature of our $a d$ hominem behaviour, yet one that has received virtually no attention from theorists. On the face of it, this is amazing. How is it to be explained?

One possibility takes note of our massive dependency on the sayso of others and the deeply entrenched disposition — or drive — to trust their assurances. As we see, much of the time, the point of the ad hominem challenge is to prompt the reassurance of the other party. It is a remarkable fact about the dialectico-epistemic lives of beings like us that we are so ready to accept the reassurances of people whom we have reason to think might not be in a good position to offer them. If we think that Harry is a liar, what good is his insistence that he is not lying now? If we have reason to believe that Harry is biased, why isn't his reassurance to the contrary tainted by that very condition? And so on. Upon reflection, we seem to have it that reassurance of the kind under review has the function of transforming a presumption into an explicit declaration. The presumption is that our interlocutors are by and large up to the task of giving their view of the matter at hand a fair run. Reassurance re-issues this presumption as a direct declaration by the party in question. What $a d$ hominem contexts suggest is that the hesitations against this presumption embedded in ad hominem retorts are subject to removal or mitigation by simple assertion to the contrary. This may strike us as decidedly odd, but there can be little doubt as to the presence of this disposition in the empirical record.

A second possibility that bears on our frequent readiness to accept the assurances of liars that they are not lying now is that by and large liars lie when it is to their advantage to do so. A truthful person honours the truth before he honours his interests. Liars reverse the ranking. In its core sense, lying is the transmission of misinformation with misinformational intent. There are contexts galore in which it is easy to see the advantages that flow to the liar from his lying. Equally, there are large classes of contexts in which lying would compromise his interests. A case in point is this dispute between Harry and Sarah. If Harry's objective is simply to get Sarah to climb down, then if Harry is a liar, it may well be in his interest to lie now. 
But if his objective is to get Sarah to see the issue that divides them as Harry knows it to be, then lying would be counterproductive. She might assent to his claim, but she could not be said to have a justified reason for holding it. In raising the flag of his notable dishonesty, Sarah issues a challenge to Harry. But she also creates a problem for herself. The problem is that of determining whether in the particular circumstances of the dispute now in progress it would be to Harry's advantage to lie and, if so, whether that advantage is weighty enough to make it likely that that is what he would in fact do.

In these contests, the object is not to get the other person to change his mind (or to shut up). The object is to get her to grasp the fact of the matter concerning the issue in dispute. Since each has this intention with regard to the other, each has a stake in one another performing as well as he or she can. ${ }^{16}$ So if Harry is a liar, and proffers information that, if reliable, damages Sarah's case, Sarah has a stake in determining the admissibility of that information. From the point of view of the protection of her turf, the course of prudence would have Sarah reject it. But given her larger objective of getting to the fact of the matter, prudence counsels that she not be precipitate or knee-jerk in her dismissals. This gives rise to what I've been calling the most important (and most neglected) feature of ad hominem challenges. Sarah must perform this balancing act without recourse to independent evidence, one way or the other, as to whether Harry is lying now (or whether the balance of his mind is disturbed now, and so on). In this regard, her situation bears some resemblance to the removal of ignorance problem in Aristotelian refutations. In each case, the problem has to be solved with strictly internal resources.

\section{Plausibility of manner}

Whether we are able to judge that a liar is lying now flows, in part at least, from the facility we have (or take ourselves as having) in assessing the plausibility of informants. A plausible witness is one who endows his assertions with "the ring of truth" in the absence of independent evidence for them-and, at times, in the face of evidence to the contrary. ${ }^{17}$ This is what might be called the plausibility of manner. It is a property of persons rather than of the propositions they attest to. Juries, for example, are frequently met with the task of determining whether a witness's manner affects to any degree the propositional plausibility or implausibility of what is asserted in his evidence. When this happens, we say that the witness's manner lends plausibility (or implausibility) to what he testifies to. In pure cases, where informant and recipient are strangers and have no knowledge of one another's track record, a witness's plausibility is betokened behaviourally, by tone of voice, the cadence, pacing and emphasis of replies, facial expression, and body language generally. Such signs are typically processed sublinguistically and subconsciously, which helps explain why linguistically-minded logicians have paid no attention to them-even those who occupy themselves with the logic of testimony ${ }^{18}$. 
It may strike some readers that the present suggestion misconceives the idea of plausibility. Perhaps this is the case, but I am not one who thinks so. If I have indeed misconceived the notion, it was not something that happened through inadvertence. This is not the place to try to settle the matter decisively. Perhaps it is enough to point out that my plausibility of manner resembles a conception of credibility, a conception in which an essential point is preserved. Credible sources can lend the ring of truth to perfectly implausible claims. If it is agreed that this is so, a problem clearly arises. In dealing with strangers, of whom nothing in particular is known or bruted, how is credibility established? Some will say that it cannot be established, except on the strength of the credibility of what he attests to. I say that this is unrealistically narrow, and that in actual practice we check faces and read body-language.

It is a fact of considerable importance that our facility with the recognition of the plausibility of informants is on the whole fairly reliable, never mind that there are clear exceptions. To the extent that this is so, an ad hominemer's provisional and qualified acceptance of the reassurances of her adversary can be supposed to be rooted in a plausibility-recognizing capacity.

The role of the plausibility of manner is also little discussed-indeed little recognized-by epistemologists and dialecticians. Yet among psychologists it has generated an already significant literature. In a number of clinical and experimental studies, the attribution of an emotion to another person—say Sarah's attribution of fear to Harry - is a matter of her responding to Harry's facial expression in ways that stimulate Sarah's amygdala, which is the part of the brain that supports her own experience of fear. On this view, the attribution of fear to another involves the simulation of it in oneself, a simulation cued by the other party's facial expression (Adolphs et al. 1994; Sprengelmeyer et al. 1999; Sripada \& Goldman 2005). This, the so-called "simulation theory" (ST), has successfully been applied to the attribution of disgust (Rolls \& Scott 1994; Small et al. 1999; Calder et al. 2000; Wicker et al. 2003). It also appears to explain the attribution of anger (Lawrence et. al. 2002; Lawrence and Calder 2004).

It would be an interesting extension of the ST of emotion-attribution if it could likewise explain the attribution to others of mental states in general, including belief. Precisely this generalization is proposed by Alvin Goldman in Simulating Minds: The Philosophy, Psychology and Neuroscience of Mindreading (2005). This is not the place to assess Goldman's theory in any detail. However, we can note that the theory has two main parts, one of which is more controversial than the other. The comparatively uncontroversial part holds that a person's mental states can be discerned albeit defeasibly in his facial expression and body language, including the character of his linguistic behaviour. The controversial part holds that such readings trigger the brain of the reader to simulate the state in question. Fortunately for my purposes here, it suffices to invoke the uncontroversial hypothesis. To put it as simply as possible, if Harry's believing that $\alpha$ is discernible 
in his facial and vocal expressions and his body language, if knowing that he believes $\alpha$ is in part a function of face-based and body-based manifestations of sincerity, then Sarah is in some position to determine whether, in this particular case, Harry is misrepresenting his beliefs. Perhaps a skilful liar would fool Sarah. But most liars are not that skilful.

We have in these reflections a general answer to the question of how Sarah is to determine whether Harry the liar is lying now. She does this by activating her belief-attribution mechanisms, and hoping for the best. It is, as mentioned, a defeasible procedure. But it is, I suggest, the way in which the plausibility of manner is reckoned.

It can hardly be denied that one of the functions of Sarah's ad hominem retort is to seek reassurance from Harry. But it also serves to put Harry on notice, to the following effect: that, if their discussion is to continue, Harry's case should take on a strength and a weight sufficient to subdue or circumvent Sarah's reservations. We may say, then, that the net effect of the challenger's ad hominem is to raise the bar of case-making as it applies to the subject of her challenge. What is normally taken as a dialectical presumption - that parties are sincere and competent -is now subject to this weak sense of showing cause that the contrary is not presently the case. So it would appear to be the ad hominem's position that if the elevated bar is not scaled, then, at a minimum, she reserves the right to withdraw for cause.

Before bringing this section to a close, it would be useful to consider a brief more general word about the dialectical role of assurance. Consider some cases. Sarah says to Harry, "I think that you might be lying". Harry replies, "I promise you that I'm not". Or Sarah says to Lou, "Harry says you were with that woman last night", and Lou replies "On my word of honour, Harry's made a terrible mistake". Or Sarah says, "I fear that bias has compromised your objectivity". Her interlocutor replies, "You need have no worry on that score". On the face of it, these are paradigm cases of dialectically impotent answers to a challenge. They are made so by the utter absence of justifying reasons in the respondent's replies. On the face of it, then, there is something wrong with Sarah's according them any degree of acceptance, however provisional and qualified. Since Sarah's position is that of all of us, it is interesting to ponder what might we say in Sarah's favour. On thinking it over, there seem to be a degree of mitigation in facts such as the following:

(1) Even liars usually tell the truth. So the default position is that Harry is not lying now.

(2) People of strong feeling are usually capable of maintaining their intellectual balance. So the default position is that Harry has not lost intellectual control of the present issue.

(3) People are capable of fairly defending positions with which they may personally disagree or attacking positions which personally they 
find no fault with. So the default position that Harry is not now acting unfairly.

(4) Case-making corruptions are open to detection and possible correction via an opponent's critical probes. So the default position is that weaknesses in Harry's case are discernible in principle.

(5) People often disconform to their own good advice through weakness of the will. So the default position is that Harry's behavioural disconformity doesn't preclude Harry's having a defeasible position on the issue at hand.

And, again,

(6) Truthfulness, and its opposite, are often discernible in facial and vocal expression and body language. So the default position is that if Harry is sincere (or insincere) this will in principle be discernible in his manner.

It is well to emphasize that these are defaults, not guarantees. When something rides on it, it needn't be wrong to raise the possibility that in the present circumstances the default doesn't hold.

\section{Reprise}

This would be a good point at which to entertain an objection that some readers might wish to press. It is that by and large the quality of an argument is independent of the qualities of the person who advances it. Accordingly the duty of the assessor is to take the measure of his interlocutor's argument, rather than the arguer himself. True, there may be exceptions to this, as in witness testimony, the appeal to authority and sayso information, but we shouldn't allow exceptions to be canonical for the thing itself. I concede that this is by far the standard explanation of the fallaciousness of the ad hominem, but I don't agree that it is the correct explanation. Let us allow that when an arguer's situation is irrelevant to the case he has advanced, then making the arguer's situation a factor in the assessment of his argument is a mistake. But it is not a fallacy unless it is a mistake committed with a requisite frequency. It seems to me quite clear that ad hominems of irrelevance don't meet this condition. Of course, sometimes disputants slang one another. But, as I said at the beginning, the object of slanging is not to discredit an opponent's argument, but rather to embarrass, mortify or infuriate him. Slanging isn't argument assessment. It is also true that sometimes disputes are mere debates, indulged in for the fun of it or for some more serious ulterior purpose, such as getting Lou an acquittal. In these cases, it is known by all that each party is engaged in one-sided argument designed to produce assent (or silence) rather than get at the truth of the 
matter. In such cases, parties ride these respective biases to the hilt. If this were occasion to challenge one another's bona fides or simply to quit the field, then we would see this well-evidenced in practice. But we don't see it in practice with anything like the frequency required by the EAUI-conception of fallaciousness. The dominant empirical fact is that, slanging apart, people make ad hominem challenges when they think that doing so is of some relevance to the worth of the addressee's case. And, as I have said, it is a further fact of our actual practice that raisers of these doubts are by and large competent judges of when they have relevance and when they don't. If this is right, the practice cannot be EAUIfallacious.

Consider briefly another trio of cases. There are issues galore of such complexity, and people galore of such gormlessness, that it would be folly to listen to, never mind taking the pains to assess, arguments about, e.g., quantum non-locality forwarded by a person of, e.g., immense stupidity. In that case, the sensible course is not to bother with him. Certainly, if one did bother with him, the chances of his getting quantum non-locality right are practically nil; and this is so because he is so stupid. Perhaps one can see the point of saying this to another party (perhaps someone who doesn't realize that quantum non-locality is simply beyond one's interlocutor). Equally, there would be no point in saying this to one's stupid vis-àvis. Doing so would, for him, have the character of slanging. But either way, it would not be a fallacy.

A second case is taken from (Johnson and Blair 2006, 99).

An irrelevant attack on the person instead on the position, is the fallacy called ad hominem. Here's an example. In his 1989 book, The Closing of the American Mind, Allen Bloom attack rock music as an overtly sexual form of music which contributes to an overall climate of promiscuity .... In a review in Rolling Stone, William Grieder wrote:

Bloom's attack is inane. Still the professor is correct about one important distinction between the kids of the 50s and those of the 80s: in the 50s the kids talked endlessly about sex; today the young people actually do it. ${ }^{19}$ This seems to drive the 56 year old Bloom-who is still a bachelor-crazy. Bloom denounces Jagger with such relish that one may wonder if the professor himself is turned on by Mick's pouty lips and wagging butt.

Johnson and Blair take this as typical of the abusive version of the fallacy. Grieder's attack, they say, is "largely personal", full of innuendo. Instead of attacking Bloom's dubious causal claim, Grieder snidely insinuates that Bloom is a repressed homosexual. "But", they say, "even if this were true, it would not have any relevance to an appraisal of Bloom's argument. Bloom's argument is about the effects of rock music on sexuality; his own sexuality is not at issue".

Well, let's see. First, where are Bloom's arguments? I myself can't find any. True, he does make the causal claim that rock promotes sexuality, which is certainly true. Bloom also implies that promiscuity is a bad thing. Grieder's responses are 
telling. First, he does not attack Bloom's causal claim. He accepts it. In fact, he rejoices in it. What rankles Grieder is Bloom's denunciation of promiscuity. In his response, Grieder makes no attempt to undo Bloom's argument for his rejection of promiscuity; but this is because Bloom advances none, expressly or implicitly. What, then, is Grieder about? He thinks — certainly he insinuates— that Bloom is a repressed homosexual alarmist, terrified of being outed - as he would be a few years later by his buddy Saul Bellow. Grieder is suggesting that Bloom's opposition to promiscuity is insincere or unbalanced, a product of the troubled denial of his own sexuality. There is reason to think that this is so. Grieder, himself a promoter of promiscuity, is making the point that an insincere denunciation of it, even by a literary critic of Bloom's standing, is insufficient ground to give it up. Grieder is right. It is also true that Grieder is scum. Someone should teach Grieder some manners. But there's nothing wrong with his reasoning.

Here is a third case. Somewhere in Technology and Empire (Grant 1969) George Grant is critical of North American Jews for having squandered their large talents on the vulgarizations of mass culture. No one to my knowledge has ever accused Grant of anti-semitism, and I rather imagine that his remarks occasioned little notice in New York or Hollywood. But suppose now that you have the misfortune to be pitched to the same effect by a neo-Nazi skin-headed, thug - tattoos, body piercings and all. If we follow the traditional wisdom, then, if I am prepared to give Grant's argument a hearing, I cannot consistently not give young Adolph's argument a hearing. But what counts here is that argumentation is nearly always discretionary. I am under no obligation to bother with Grant. I am under no obligation to engage with Adolph. Whether I do is up to me. It doesn't need a justification. Speaking for myself, while I would spend an hour or so going over this with Grant, I wouldn't give the punk the time of day. I happen to think that Grant is wrong in suggesting that North American Jews have dishonoured their talents. If that were also Adolph's view, it would also be wrong. But, while I would take it up with Grant, I wouldn't with Adolph.

Those who favour the "non-interactive" model of argument assessment will undoubtedly point out that the logician's task is to evaluate the argument irrespective of who advances it. I have three things to say about this. First, when this is in fact what's happening, it follows from the definition of "non-interactive", and hence is trivial, that reference to Grant's anglophilia or to Adolph's thuggery is irrelevant. So it is also trivial that if offered as telling for or against the non-interactive argument it would be unavailing. A second point is that in non-interactive argument analysis —of the sort undertaken by academic philosophers—ad hominem remarks occur with nothing like the frequency that would qualify them as fallacies. How many philosophers do we know who mock Aquinas' Five Ways on grounds that he is a forlornly pre-committed theist? The third point is that where ad hominem exchanges are most frequent—and wholly natural — are interactive contexts, where they are subject to all the rich, and largely benign, variability that we have been at pains here to expose. 


\section{Ad hominem inference?}

People who are in the post-1847 tradition claim that the ad hominem involves an error of inference. We may schematize the inference as follows:

1. Sarah makes her ad hominem retort.

2. She concludes from this that the adequacy of her opponent's case is called into doubt.

3. She concludes from this that there is reason to think that her interlocutor's position is false.

No one denies that without the qualifications "in doubt" and "reason to think" this is a pretty suspect argument, and a manifestly bad one if intended deductively.

It is at this point that we encounter an individuation problem. Some people are of the view that an argumentum ad hominem is constituted by all three components, the retort of (1) and the inferences of (2) and (3). So understood - and leaving to one side for now the question of the presence or absence of deductive intent-an ad hominem begins with (1) and ends with (3). Others are of the view that the ad hominem has a slighter constitution, one that begins with (1) and ends with (2). We have it, then, that in any dispute about whether the ad hominem is a fallacy, it is necessary that we solve this individuation problem. Complicating this issue is the question of deductive intent. Let us try to deal with it first. Even with the qualifications "in doubt" and "reason to think", there can be no serious question that the inferences at both (2) and (3) are invalid. If so, this takes the pressure off the individuation question, since whether the ad hominem ends at (2) or at (3), it is an inferential failure both times. But is it a fallacy?

\section{An autoepistemic argument}

If the question before us is whether the mistake of inferring with deductive intent (2) alone, or (2) and (3) together, is a fallacy, the answer is that it is not. For, while drawing these conclusions with deductive intent is an error, there is not a jot of evidence in the empirical record to suggest that, when these inferences are made in real-life, they are typically (or even frequently) drawn with deductive intent. Consequently they fail the attractiveness, universality and incorrigibility conditions on fallaciousness. (See section 1 above.)

What if the intent is other than deductive? I have no solid answer to this question. In this I believe that I am not alone. Part of the difficulty is that, as the empirical record again will attest, typically our ad hominem behaviour on the ground carries with it an indeterminacy that underdetermines even the fairly simple schema that we are currently postulating, and certainly does not in general help us in solving the individuation problem. It is true that the presence of the qualifiers "in doubt" 
and "reason to think" indicate the presence of some non-deductive consequence relation, which might be thought to underlie some or other form of presumptive or (perhaps plausibilistic) reasoning. But the logic of presumption and plausibility is so far from having been worked out definitively, that citing it at this stage is more promissory than helpful. ${ }^{20}$ In the circumstances, perhaps we can do no better than yield to the guidance of the principle of charity, putting it that if the inference of (2) (or (2) and (3)) is said to be an error, albeit a non-deductive one, the burden of proof rests with him who makes the accusation.

The burden of proof also suggests a presumption of innocence. If it falls to the charger of fallacy to show that ad hominem inferences actually embed some, as yet not theoretically well-understood, non-deductive consequence relation which our ad hominem behaviour routinely mismanages, then, until that onus is met, the charge of fallacy is unfounded. I doubt whether this onus can be met at present. Doing so would require the critic to show that there is no consequence relation thanks to which these inferences are in some sense reasonable - that there is nothing whatever to be said for them. For all the strides made since Bolzano and Tarski, the general logic of consequence is not in nearly good enough shape to make this a forseeably attainable target. Even if we allow that there is an inductive consequence relation that is well catered-for by conditional probability, most of the work on ampliative consequence is still to be done. ${ }^{21}$

Doubtless some readers will find this a trifle over-defensive and "legalistic". Surely something more forthcoming can be offered in support of the negative thesis. Let us see. Consider a class of cases. These are cases in which the point in contention is one of serious importance to the parties, and where there already exists a substantial record of advocacy and counter-advocacy surrounding it. This might even be something that has already been pretty much "argued to death". Let it be the case, in particular, that Harry is a well-known and rather fanatical spokesman for $\alpha$, the Netherlands' policy of physician-assisted suicide. Sarah now makes her ad hominem intervention: "Look, Harry, the fact that this is still an open question after all, we're still arguing about it - tells us that you have not succeeded in discharging your burden by making the case for $\alpha$. Doesn't this show that there is something wrong with that case?"

In effect, Sarah has drawn a type-2 conclusion from the fact attributed in her ad hominem remark. Could she now with any plausibility go on to draw a type-3 conclusion? It would seem that she could. Granted that Harry's case is now in some doubt, Sarah might reason autoepistemically, as follows. ${ }^{22}$

1. If there were a sound case for $\alpha$, then surely Harry, of all people, would have it in hand by now.

2. But, as we see, there is reason to think that he doesn't.

3. So it can be doubted that a successful case for $\alpha$ exists.

4. Moreover, if $\alpha$ were actually true, it is reasonable to suppose that by now a successful case for it would have presented itself. 
5. But so far we know of no such case.

6. So there is some reason to think that $\alpha$ is not true. ${ }^{23}$

It is interesting to note that Sarah's hypothetical autoepistemic argument embeds two of what Isaiah Berlin identifies as the defining conditions of the Enlightenment's conception of rationality (Berlin 1999, 21-22). One is that every question has a determinately correct answer. The other is that, with regard to all issues, sooner or later the truth will out. If we allow these assumptions to stand, Sarah's reasoning, tentative though it rightly is, has merit. In her dispute with Harry, the burden of proof rests with him. The merit of Sarah's argument is that it casts doubt on whether Harry can meet it.

We should not, of course, give these assumptions a free pass; nor, as a devoted critic of them, would Berlin wish us to do so. The kind of pluralism espoused (but not very well explained) by Berlin leaves it open that these assumptions are incorrect. In which case, it becomes a question of dominant importance as to which are the questions that lack determinate answers and concerning which the truth will not out. This accords to Sarah's autoepistemic reasoning the necessity to amend its ultimate conclusion, (6). In its place, we write

(6') So there is some reason to think that either $\alpha$ is not true or that there is no determinate answer as to whether it is true as opposed to false, or false as opposed to true.

Either way, this is bad news. In the first instance, it is bad news for Harry. In the second instance, it is bad news for them both. In neither case, however, does "bad" mean awful. Even if there is reason to think these bad consequences might obtain, it is far from certain that they do. Optimists will want to press on, hoping for greater determinacy down the road. Pessimists, on the other hand, should probably call it a day.

\section{Dialectically benign?}

So much for the negative thesis. What might be said about its positive vis-à-vis? Ad hominem remarks are challenges. By and large, they are not deal-breakers. They put the ad hominem's interlocutor on notice, and they invite him to do what he can to remove or circumvent his challenger's doubts about his bona fides as a case-maker concerning the issue that presently divides them. When Sarah and Harry have a stake in getting it right as to whether the Netherlands' policy is morally sound, they have a stake in jointly producing as objective an examination of reasons pro and con as lies within their means. They also have a stake in not quitting the issue prematurely. The ad hominem retort is an aid to both objectives. It warns the other party about possible difficulties with his case-making wherewithal, but it also keeps the discussion going. In extremis, it presents the other party with 
a (usually implicit) autoepistemic argument in the form (1) to (6'). It presents it as a challenge. It is a way of keeping the advocacy honest short of falling into irreconciliation or, as Locke says, silence. If that is not a virtue, I don't know what is.

\section{Normatively tenable?}

Logicians with a hankering for the normative may be quick to condemn the present line of thinking as naïve to a fault, perhaps even as a betrayal of rationality. I won't take the time to say here why I think that such a judgement would miss the mark. Suffice it that if it is irrational to persist with an opponent whose situation legitimately calls into doubt his adequacy as a case-maker for the proposition he is arguing for, it is not an irrationality that attaches to her ad hominem. For the ad hominem raises the doubt, it does not compel persistence. We may see the point at issue as resembling a pragmatic syllogism in Aristotle's sense, along the following lines.

1. $P$. [Ad hominem retort]

2. $P$ is reason to question the other party's case-making bona fides. [Verbal conclusion]

3. \{The ad hominemer does not quit the discussion\}. [Practical conclusion: an action]

Whether the action represented at (3) is the rational thing to do, or otherwise, it is a response to an ad hominem. It is not the ad hominem itself, either in the form of a type- 2 inference or type- 3 inference. People might argue that the correct response to those inferences is to withdraw from the fray. Perhaps, contrary to what I think, this is the rational thing to do. But if so, it presupposes the tenability of those ad hominem inferences. If fault there be, it is not with the ad hominem. The question of its fallaciousness doesn't arise.

\section{Rudeness and worse}

It is worth repeating that for the most part disputes are engagements by mutual consent. They are entered into voluntarily, and parties are free to leave them more or less at will. It can hardly be surprising that such arrangements are governed, albeit sometimes quite loosely, by conventions of civility. ${ }^{24}$ It takes some skill to launch an embarrassing ad hominem against an interlocutor without occasioning his departure or transforming the exchange into a slanging-match. Certainly one does not want too often to succumb to the rhetorical delights of saying to one's opponent that he is a chichi sneakbill rogue or a niggish deformed sot, even when these things are true. It is here that the post-1847 "tradition" is on to something. The more an embarrassing disclosure is irrelevant, that is, the less it supports a type- 2 and/or type- 3 inference, the likelier the shared objectives of the disputation 
are imperilled. One assocates such a view with Douglas Walton, e.g., (Walton 1998). It embodies an interesting idea. But it is not enough to show that a to show that the ad hominem is a fallacy on the EAUI-conception of it. Indeed for it to be a fallacy at all, it would be necessary to reconceptualize the very idea of it. ${ }^{25}$ This is not the place to fret over-much about the ins-and-outs of definitional conceptual change or its risk of simple tendentiousness. Suffice it to say that in the sense intended by the modern founder of the view that ad hominems are fallacious, inducing your opponent to quit the argument in a huff, to say nothing of punching you in the nose, is nothing like a fallacy in De Morgan's sense. Fallacies are not dialogue-wreckers. They are mistakes of reasoning.

The view that a fallacy is an illicit move in a dialogue, made so by its propensity (and perhaps intent) to frustrate the rightful objectives of the exchange, exemplifies a drift away from the historic view that fallacious reasoning falls within the province of logic. It is a deviation with a discernible structure. In its first phase, fallacies are construed as dialectical infelicities (Hintikka 1987; Walton 1995; van Eemeren and Grootendorst 1983). In the second phase, dialectic is permitted to blur the ancient distinction between logic and rhetoric (Johnson 2000). In consequence, reminding your interlocutor that he is a niggish deformed sot is, in virtually all contexts, argumentatively stupid, hence certainly a dialectical infelicity, hence, on that conception of it, a fallacy. ${ }^{26}$

\section{Logic}

The growing dominance of this pragma-dialectical approach is a mixed blessing for the fallacies. On the one hand, there are scads of fallacies that have no essential tie to dialectical contexts; still less do they possess dialectical "structures". ${ }^{27}$ Again, this means that the analysis of such fallacies in a dialectical theory of argument is, short of a re-definition of fallacy - bound to work a significant distortion into the ensuing account. One can make the compensating adjustments stipulatively if one chooses. But, as a general rule, nominal definitions aren't just free for the asking. One needs to be sold on their virtues.

If dialectic is the "over-sold" half of the pragma-dialectical pair, pragmatics has a much greater claim to centrality. It is widely agreed that the four princely precincts of mathematical logic — set theory, model theory, proof theory and recursion theory-are devoid of people. So constrained, logic has no interest in either context or agency. This alone limits mathematical logic to at best a supporting role in theories of contextually-sensitive, agent-based reasoning, which is precisely the sort of thing that informal logic is. By a natural generalization of C.W. Morris' conception of the pragmatics of language (Morris 1971), this makes informal logic an inherently pragmatic enterprise..$^{28}$ It is a virtue of the pragma-dialectical approach generally, and of Douglas Walton's more recent writings over the past twenty years, to give to this pragmatic dimension the theoretical emphasis that is clearly due it (Walton 1990; 1995). 
Let me say again that it is not my purpose to suggest that such stipulative reorientations are always out of place. (The concept of body had to be changed to accommodate quantum physics. The concept of straight line had to be adjusted to deal with relativity theory.) Still, it might strike readers as somewhat odd that some of those who abandon the traditional view of fallacies as logical errors do so under the mantle of what they allow themselves to call "informal logic". ${ }^{29}$ If that weren't - for traditionalists - a wrenching enough alienation, the repudiation of logic by fallacy theorists is compounded by the abandonment of fallacies by logic, that is, by mainstream mathematical logic and its principal variations. Charles Hamblin famously proposed a repair of the latter by way of the former (Hamblin 1970). Hamblin is certainly right to say that, left to its own context-free and agentindependent devices, logic will never manage to get the right answers to the fallacy theorist's questions; in fact, it won't be able to formulate them. The dialectification of logic à la (Barth and Krabbe 1982) has a great deal to recommend it. But it is folly to suggest, as some do, that this encompasses all of logic. This is not the place to plead the contrary case in greater detail, but I do want to say that if the analysis of the ad hominem outlined in these pages has merit, we now have reason to believe that, were the post-1847 argumentum ad hominem a fallacy, it would be an error of inference, hence would fall within the embrace of logic. ${ }^{30}$ Another way of saying this is that it falls to logic to determine whether the ad hominem is an error of reasoning. The verdict of logic is that it is not. ${ }^{31}$

\section{Notes}

${ }^{1}$ For valuable criticisms and suggestions I warmly thank David Godden, David Hitchcock, Hans Hansen and Ralph Johnson. As always, I am most grateful to Carol Woods for technical support. ${ }^{2}$ Quoted from (Davies 1979, 8).

${ }^{3}$ See also (Govier 1995, 172): "By definition, fallacy is a mistake in reasoning, a mistake which occurs with some frequency in real arguments and which is characteristically deceptive". See also (Scriven 1987, p. 333): "Fallacies are the attractive nuisances of argumentation, the ideal types of improper inference. They require labels because they are thought to be common enough or important enough to make the costs of labels worthwhile ...". Some such view is also endorsed by (Hitchcock 2006, 1) as "the standard conception of a fallacy in the western logical tradition ...." ${ }^{4}$ In (Woods et al. 2004) the Gang of Eighteen are: ad baculum, ad hominem, ad misericordiam, ad populum, ad verecundiam, ad ignorantiam, post hoc, ergo propter hoc, affirming the consequent, denying the antecedent, begging the question, equivocation, amphiboly, hasty generalization, biased statistics, composition and division, faulty analogy, gambler's and ignorato elenchi.

${ }^{5}$ Diehards may think this a trifle question-begging. They will think that the ad hominem has been a fallacy all along, and that the discovery of its true nature had to wait for 2200 years.

${ }^{6}$ For an excellent survey, see (Nuchelmans 1993).

${ }^{7}$ A fallacy, that is, in the most basic of the ordinary senses of the word - a common or widespread misconception.

${ }^{8} 20,177^{\mathrm{b}} 31-34,22,178^{\mathrm{b}} 16-23$. cf. $8,170^{\mathrm{a}}, 12-19$.

${ }^{9}$ Locke's conception is broader. When a Lockean ad hominem succeeds, it reveals that its addressee holds views that damage (but not necessarily contradict) his own thesis.

${ }^{10}$ In the spirit perhaps of the response of the Chancellor of the Exchequer to the present Prime Minister of Britain: "There is nothing you could ever say to me now that I could ever believe." 
Quoted in a review of (Peston 2006) by Peter Clarke in the Times Literary Supplement, June 30, 2006. p. 12.

${ }^{11}$ It would not be too much to say that beings like us have a drive to accept the sayso of others. So whether it is indeed better to do so in the general case or not, we don't have much of an option. ${ }^{12}$ The dialectical role of mind-closure is investigated in the eponymous dialogue game, MindClosed, developed in (Gabbay and Woods 2001b) and (Gabbay and Woods, 2001c).

${ }^{13} \mathrm{Cf}$. Mill on "free discussions", which are characterized as free and equal, and fair and thorough (Mill 1869, pp. 9, 10, 20, 24-26, 30, 44).

${ }^{14}$ There are two different conceptions of pragmatic inconsistency discernible in the present-day literature. One is a kind of behavioural incompatibility between what a person practices and what he advocates. This is the conception invoked in this note. The other is a blindspot-creator (Sorensen 1988), occasioned by a conflict between utterance-conditions and truth-conditions (e.g., " $P$, but I don't believe it" or "I can't speak a word of English").

${ }^{15}$ This possibility is developed in greater detail in (Woods 1993).

${ }^{16}$ Although listed by Aristotle separately from refutation arguments, in the conditions of real-life, elements of refutation may occur quite naturally in the transaction of examination arguments.

${ }^{17}$ A more detailed discussion of the metaphor of the ring of truth can be found in (Gabbay and Woods 2007).

${ }^{18}$ E.g. (Coady 1992).

${ }^{19}$ Clearly Grieder wasn't around in the 50s!

${ }^{20}$ For an interesting attempt, see (Rescher 1976). See also (Walton 1996). For a non-Rescherian approach to plausibility, see (Gabbay and Woods 2007).

${ }^{21}$ For example, abductive consequence is not yet a closed question for logic. See (Gabbay and Woods 2006a).

${ }^{22}$ And, in so saying, an aspect of the ad ignorantiam enters the picture; but, here too, it enters non-fallaciously.

${ }^{23}$ I take it that since $\sim \alpha$ was long since the established position in the Netherlands (and everywhere else) - in fact, is a kind of taboo - the burden of proof lies with Harry. For an explanation of why Sarah's position with regard to is not subject to the same kind of type-2 and/or type-3 argument from Harry, see (Woods 2000) on the dialectical frailty of taboos.

${ }^{24}$ Some argument-types are uncooperative without being necessarily uncivil; certainly they proceed to some purpose well-short of anarchy. See again (Gabbay and Woods 2001b; and Gabbay and Woods 2001c).

${ }^{25}$ This is something that the pragma-dialecticians have done, but-strangely to my mindwithout acknowledgement. See (van Eemeren and Grootendorst 1983; Woods 2004, chapter 9). ${ }^{26}$ In recent writings, Frans van Eemeren and Peter Houtlosser have attempted to preserve a principled distinction between dialectic, as they conceive of it, and rhetoric. It is early days, but I do not see that they have yet succeeded in doing so in a very natural or intuitive way (van Eemeren and Houtlosser 2000). The problem, as I see it, is that their conception of rhetoric both contrasts with and is an extension of the pragma-dialectical model of dialectic. In my view, this latter is an unrepresentative model of dialectical argumentation in real-life settings (Woods 2006a). Accordingly, in its contrastive relation to an unrepresentative model, the model of rhetoric inherits some of this distortion. But, as I say, it is early days for this research programme. It may be that my reservations will eventually prove to be groundless.

${ }^{27}$ For example: affirming the consequent, denying the antecedent, the gambler's fallacy, post hoc, ergo proper hoc, composition, division, hasty generalization, biased statistics and ad ignorantiam. I note in passing that I am inclined to think that in the case of individual, as opposed to institutional, agents, none of these is a fallacy on the EAUI-conception of them. See (Woods 2004, chapter 1). But this is beside the present point. Fallacies or not, these manoeuvres are not inherently dialectical. ${ }^{28}$ The generalization adds to the speaker-use aspect of Morrisian pragmatics, facts about the psychological constitution of the cognitive agent. So in this sense the pragmatic dimension re- 
psychologizes logic. See here (Pelletier and Elio 2005; Gabbay and Woods 2006b). By these lights, non-interactive argument assessment is too truncated. Imagine that you see, written on someone's back fence, the following sequence of sentences: $\left\langle\alpha_{1}, \ldots, \alpha_{\mathrm{n}}, \beta\right\rangle$ it is demonstrable that this argument is invalid. Should we conclude from this that it is a bad argument? We should do no such thing. Whether an argument is vitiated by its invalidity is a function of what the arguer's cognitive target was and of the attainment-standards that it embeds. It bears on this that when advanced by beings like us, most good arguments are invalid.

${ }^{29}$ Exceptions include (Govier, 1987) and (Johnson 2000).

${ }^{30}$ For ways in which to contextualize logic around a concept of the reasoning agent, see (Gabbay and Woods 2001a; 2003a; 2003b; 2005; 2007).

${ }^{31}$ In the misty long ago, Douglas Walton and I published some twenty-five or so papers that constituted what came to be known as the Woods-Walton Approach to fallacy theory. Most of these are collected in (Woods and Walton 1989). Two of them dealt with the ad hominem. Although now disavowed by each of us, albeit for different reasons, perhaps it may be said that it was a virtue of the Woods-Walton Approach to reveal that, in a majority of cases, the more or less traditional examples of the fallacies responded to the following distinction. Consider the expression "the $X$ fallacy". Then, it is possible to specify arguments that instantiate ' $X$ ' which nevertheless are not fallacious. In other words, being an argument of the $X$-sort underdetermines whether it is a fallacy. When we began the fallacies project in the early 1970 s, logic was in the midst of an exciting and explosive pluralism. We were then of the view that mainstream mathematical logic couldn't be made to work for the fallacies - aside possibly from the strictly formal ones, such as affirming the consequent. However, having seen the large influence of the new logics on the philosophy of natural languages, we thought that fallacious reasoning might find a comfortable home there as well. So we looked to Kripke's modal semantics for intuitionistic logic for help in blocking circularity and to developments (mainly our own) in dialogue logic to drive the analysis of the petitio. We turned to relatedness logics for elucidations of irrelevance. Composition and division we placed within a theory of aggreggates that we adapted from Tyler Burge. But, as with the ad hominem itself, we were also aware early on that pragmatic analyses would be required, in order to take proper measure of the properties of interlocuting agents. By the mid-eighties, when we started to drift into solo work, I became growingly dissatisfied with the logics of the 1970s and early 1980s, chiefly for their want of attention to what agents are actually like. Doug shared some of these misgivings, but was more convinced than I (and still is) of the dominant importance of dialectical considerations for a general account of fallaciousness, and there has been a marked development of his views from obligation games to the "new dialectic". Well, that is a brief snippet of history. Doug Walton went on to produce what must be the largest research record by a single individual in the over 2000-year history of logic, a remarkable accomplishment by any measure. In 1998 there appeared Ad Hominem Arguments (Walton 1998). Here, as in all his solo writings, there is evidence of the influence of a practically tinged dialectical orientation, including its normative presumptions. I have come to think that, with rare exceptions, logicians and argumentation theorists have achieved no success whatever in justifying their normative preconceptions, in consequence of which I have learned to give pride of place to the empirical record (Woods 2003, chapter 8; Gabbay and Woods, 2003b). The exception is a version of fallibilism according to which the theorist's default position should be that how a human agent does in fact reason is by and large how he should reason. Perhaps this is a mistake. But, mistake or not, it has helped prompt the views developed here, which are a departure from the commanding heights of Ad Hominem Arguments, and, as I will be the first to say, will have a hard time besting it.

Douglas Walton was my student at the University of Toronto, then a valued collaborator, then an admired colleague, and a friend throughout. There is no larger presence in contemporary argumentation theory, and I am honoured to dedicate this small bit of heterodoxy to him, with salutçs and regards. 


\section{References}

Adolphs, R., Tranel, D., Damásio, H. \& Domásio, A. (1994). Impaired recognition in facial expressions following bilateral damage to the amygdale. Nature, 372, 669-672.

Aristotle. (1984). The Complete Works of Aristotle, vol. 1, Jonathan Barnes (Trans. and Ed.). Princeton NJ: Princeton University Press.

Berlin, Isiah. (1999). The Roots of Romanticism: The A.W. Mellon Lectures in the Fine Arts, 1965. Henry Hardy (Ed.). London: Chatto and Winders.

Barth, E.M., \& Krabbe, E.C.W. (1982). From Axiom to Dialogue: A Philosophical Study of Logic and Argumentation. Berlin and New York: De Gruyter.

Calder, A.J., Keane, J., Manes, J., Antoun, N., \& Young, A.W. (2000). Impaired recognition and experience of disgust following brain injury. Nature Review Neuroscience, 3, 1077-1078.

Coady, C.A.J. (1992). Testimony: A Philosophical Study. Oxford: Oxford University Press.

Davies, Robertson. (1979). The relevance and importance of the humanities in the present day. In John Woods \& Harold Coward (Eds.), Humanities in the Present Day (pp. 110). Waterloo, ON: Wilfrid Laurier University Press.

DeMorgan, Augustus. (1847). Formal Logic, or the Calculus of Inference, Necessary and Probable. London: Taylor and Walton.

Eemeren, Frans H. van, \& Grootendorst, Rob. (1984). Speech Acts in Argumentative Discussions. Dordrecht: Foris Publications.

Eemeren, Frans H. van, \& Houtlosser, Peter. (2000). Rhetorical analysis within a pragmadialectical framework. Argumentation, 14, 293-305.

Gabbay, Dov M., \& Woods, John. (2001a). The new logic. Logic Journal of the IGPL, 9, 157-190.

Gabbay, Dov M., \& Woods, John. (2001b). Non-cooperation in dialogue logic. Synthese, 127, 161-186.

Gabbay, Dov M., \& Woods, John. (2001c). More on non-cooperation in dialogue logic. Logic Journal of the IGPL, 9, 321-339.

Gabbay, Dov M., \& Woods, John. (2003a). Agenda Relevance: A Study in Formal Pragmatics, volume 1 of A Practical Logic of Cognitive Systems. Amsterdam: North Holland.

Gabbay, Dov M., \&Woods, John. (2003b). Normative models of rationality: The disutility of some approaches. Logic Journal of the IGPL, 11, 597-613.

Gabbay, Dov M., \&Woods, John. (2005). The Reach of Abduction: Insight and Trial, volume 2 of A Practical Logic of Cognitive Systems. Amsterdam: North Holland, 2005.

Gabbay, Dov M., \&Woods, John. (2006a). Advice on abductive logic. Logic Journal of the IGPL, 14, 189-219.

Gabbay, Dov M., \&Woods, John. (2006b). Resource-based origins of non-monotonicity. Studia Logica, to appear.

Gabbay, Dov M., \&Woods, John. (2007; to appear). The Ring of Truth: Towards a Logic of Plausibility, volume 3 of a Practical Logic of Cognitive Systems. Amsterdam: Elsevier/North-Holland. 
Gabbay, Dov M., \&Woods, John. (2008; to appear). Seductions and Shortcuts: Fallacies in the Cognitive Economy, volume 4 of A Practical Logic of Cognitive Systems. Amsterdam: Elsevier/North-Holland.

Goldman, Alvin I. \& Sripada, C.S. (2005). Stimulating Minds: The Philosophy, Psychology and Neuroscience of Mindreading. New York: Oxford University Press.

Govier, Trudy. (1987). Problems in Argument Analysis and Evaluation. Berlin: de Gruyter/ Foris.

Govier, Trudy. (1995). Reply to Massey. In Hans V. Hansen \& Robert C. Pinto (Eds.), Fallacies: Classical and Contemporary Readings (pp. 172-180). University Park, PA: The Pennsylvania State University Press.

Grant, George. (1969). Technology and Empire. Toronto: House of Anansi.

Hamblin, C.L. (1970). Fallacies. London: Methuen.

Hintikka, Jaakko. (1987). The fallacy of fallacies. Argumentation, 1, 211-238.

Hitchcock, David. (2006). Why there is no argumentum ad hominem fallacy. www.humanities.mcmaster.ca/ hitchckd/. (Accessed on 15/07/06).

Johnson, Ralph H. (2000). Manifest Rationality: A Pragmatic Theory of Argument. Mahwah, NJ: Laurence Erlbaum Associates.

Johnson, Ralph H., \& Blair, J. Anthony. (2006). Logical Self Defense, New York: International Debate Education Association.

Lawrence, A.D., Calder, A.J., McGowan, S.M., \& Grasby, P.M. (2002). Selective disruption of the recognition of facial expressions of anger. NeuroReport, 13, 881-884.

Lawrence, A.D., \& Calder, A.J. (2004). Homologizing human emotions. In D. Evans and P. Cruse (Eds.), Emotions, Evolution and Rationality (pp. 15-47). New York: Oxford University Press.

Locke, John. (1690/1975). An Essay concerning Human Understanding. Peter H. Niddich (Ed.). Oxford: Oxford University Press.

Mill, J.S. (1978). On Liberty. E. Rapaport (Ed.). Indianapolis: Hackett.

Morris, Charles W. (1971). Writings on the General Theory of Signs. The Hague: Mouton.

Nuchelmans, G. (1993). On the fourfold root of the argumentum ad hominem. In E.C.W. Krabbe, R.J. Dalitz, \& P.A. Smit (Eds.), Empirical Logic and Public Debate: Essays in Honour of Else M. Barth (pp. 37-47). Amsterdam: Rodopi.

Pelletier, F.J., \& Elio, R. (2005). The case for psychologism in default and inheritance reasoning. Synthese, 46, 7-35.

Peston, Robert. (2006). Brown's Britain. London: Short Books.

Plato. (1980). Meno. In E. Hamilton \& H. Cairns (Eds.), Plato: The Collected Dialogues. Princeton: Princeton University Press.

Poole, David. (1988). A logical framework for default reasoning. Artificial Intelligence, 36, 27-47.

Rescher, Nicholas. (1976). Plausible Reasoning: An Introduction to the Theory and Practice of Plausible Inference. Assen and Amsterdam: Van Gorcum.

Rolls, E.T., \& Scott, T.R. (1994). Central taste anatomy and neurophysiology. In I.R.L. Doty (Ed.), Handbook of Olfaction and Gustation. New York: Dekker.

Scriven, Michael. (1987). Fallacies of statistical substitution Argumentation,1, 333-349. 
Small, D.M., Zald, D.H., Jones-Gotman, M., Zatorre, R.J, Pardo, J.V., Frey, S., \& Petrides, M. (1999). Brain imaging: human cortical gustatory areas: a review of functional neuroimaging data. NeuroReport, 10, 7-14.

Sorensen, Roy. (1988). Blindspots. Oxford: Clarendon Press.

Sprengelmeyer, R., Young, A.W., Schroeder, U., Grossenbacher, P.G., Federlein, J., Buttnes,

T., \& Przuntek, H. (1999). Knowing no fear. Proceedings of the Royal Society (Series B: Biology), 266, 2451-2456.

Sripada, Chandar Sekhar, \& Goldman, Alvin I. (2005). Simulation and the evolution of mindreading. In Atónio Zilhão (Ed.), Evolution, Rationality and Cognition (pp. 148-161). London: Routledge.

Walton, Douglas. (1990). What is reasoning? What is argument? Journal of Philosophy, 87, 399-419.

Walton, Douglas. (1992). The Place of Emotion in Argument. University Park, PA: Pennsylvania State University Press.

Walton, Douglas. (1995). A Pragmatic Theory of Fallacy. Tuscaloosa: University of Alabama Press.

Walton, Douglas. (1996). Argumentation Schemes for Presumptive Reasoning. Mahwah, NJ: Erlbaum.

Wicker, B., Keysers, C., Plailly,J., Royer, J.-P., Gallese, V., \& Rizzelatti, G. (2003). Both of us disgusted in my insula: the common neural basis of seeing and feeling disgust. Neuron, 40, 655-664.

Woods, John. (1993). Dialectical blindspots. Philosophy and Rhetoric, 26, 251-265. Reprinted in (Woods, 2004).

Woods, John. (2000). Slippery slopes and collapsing taboos. Argumentation, 4, $107-$ 134.

Woods, John. (2004). The Death of Argument: Fallacies in Agent-Based Reasoning. Dordrecht and Boston: Kluwer.

Woods, John. (2006a). Reconsidering pragma-dialectics. In Peter Houtlosser, \& Agnès van Rees (Eds.), Considering Pragma-Dialectics, (pp. 301-312). Mahwah, NJ: Erlbaum.

Woods, John, \& Walton, Douglas. (1989). Fallacies: Selected Papers 1972-1982, Berlin: de Gruyter/Foris.

Woods, John, Irvine, Andrew, \& Walton, Douglas. (2004). Argument: Critical Thinking, Logic and the Fallacies ( $2^{\text {nd }}$ edition). Toronto: Prentice Hall.

John Woods

Department of Philosophy, University of British Columbia Vancouver, B.C. Canada V6T $1 Z 1$ e-mail: jwoods@interchange.ubc.ca

Department of Computer Science, King's College London WC2R 2LS UK e-mail:woodsj@dcs.kcl.ac.uk 